\title{
KAJIAN OPTIMALISASI PENGURANGAN TITIK SAMPLING RADIOAKTIVITAS LINGKUNGAN DI SEKITAR KAWASAN NUKLIR YOGYAKARTA
}

\section{STUDY ON OPTIMIZATION OF ENVIRONMENTAL RADIOACTIVITY SAMPLING POINTS REDUCTION AROUND THE YOGYAKARTA NUCLEAR AREA}

\author{
Jasmi Budi Utami, Siswanti, Eko Lestariningsih \\ Pusat Sains dan Teknologi Akselerator - BATAN, Jl. Babarsari Kotak Pos 6101 ykbb, Yogyakarta, 55281 \\ E-mail: budi.utami@batan.go.id
}

Diterima 19 April 2021, diterima dalam bentuk perbaikan 6 Juli 2021, disetujui 3 November 2021

\begin{abstract}
ABSTRAK
KAJIAN OPTIMALISASI PENGURANGAN TITIK SAMPLING RADIOAKTIVITAS LINGKUNGAN DI SEKITAR KAWASAN NUKLIR YOGYAKARTA. Telah dilakukan kajian optimalisasi pengurangan titik sampling radioaktivitas lingkungan di sekitar Kawasan Nuklir Yogyakarta (KNY). Berdasarkan pertimbangan pemantauan lingkungan di sekitar reaktor Kartini sampai dengan radius $5 \mathrm{~km}$ adalah berlebihan maka kajian pengurangan titik sampling perlu dilakukan. Tujuan dari kajian ini adalah untuk menentukan kemungkinan pengurangan titik lokasi sampling parameter pengawasan lingkungan antara lain: air, tanah dan tanaman di lingkungan sekitar KNY. Kajian optimasi pengurangan titik sampling didasarkan pada arah angin dominan dan evaluasi data pengukuran. Data dari Stasiun Meteorologi Adi Sucipto, Yogyakarta digunakan dalam penentuan arah angin dominan dan diolah menggunakan software WRPlot. Evaluasi data dilakukan dengan menguji perbedaan antara rerata hasil pemantauan pada semua lokasi sampling dan rerata hasil pemantauan pada beberapa lokasi sampling. Evaluasi data dilakukan secara statistik menggunakan software PSPP versi 3. Hasil uji beda $t$ antara data radioaktivitas air, tanah dan tanaman pada radius 100 - $1500 \mathrm{~m}$ dan data radioaktivitas air, tanah dan tanaman pada seluruh lokasi sampling, masing-masing diperoleh Sig=0,423; Sig=0,764; Sig=0,738; hal ini berarti rerata data tidak berbeda nyata. Selain uji beda t pada parameter tersebut juga dilakukan uji beda t pada data laju dosis radiasi lingkungan, diperoleh hasil Sig=0,81 yang berarti rerata data tidak berbeda nyata. Sebaran data radioaktivitas air, tanah dan tanaman pada beberapa lokasi sampling hasil optimasi sama dengan sebaran data radioaktivitas pada seluruh lokasi sampling. Berdasarkan hasil kajian ini, dapat direkomendasikan bahwa lokasi sampling radioaktivitas lingkungan dilakukan cukup pada radius 100 $1500 \mathrm{~m}$ dari pusat reaktor.
\end{abstract}

Kata kunci: Titik sampling, radioaktivitas, lingkungan, arah angin, statistik.

\begin{abstract}
STUDY ON OPTIMIZATION OF ENVIRONMENTAL RADIOACTIVITY SAMPLING POINTS REDUCTION AROUND THE YOGYAKARTA NUCLEAR AREA. A study on optimization of environmental radioactivity sampling points around the Yogyakarta Nuclear Zone (KNY) has been conducted. Based on the consideration that environmental monitoring around the Kartini reactor up to a radius of $5 \mathrm{~km}$ is excessive so a study to reduce the sampling point is necessary. The purpose of this study is to determine possible reduction of observation points for environmental monitoring parameters, including: air, soil and plants in the environment around KNY. The point innovation study is based on the dominant wind direction and evaluation of measurement data. Meteorologycal data from Adi Sucipto Station is used for determination of the dominant wind direction and processed using WRPlot software. Data evaluation was carried out by examining the difference between the mean observed results at all locations and the mean results at several sampling locations. Data evaluation was carried out statistically using PSPP version 3 software. The results of significant difference test between water, soil and plant radioactivity data in radius of $100-1500 \mathrm{~m}$ and the radioactivity data of water, soil and plants at all sampling locations, respectively are $\mathrm{Sig}=0.423$; $\mathrm{Sig}=0.764$; $\mathrm{Sig}=0.73$; It means the mean data is not significantly different. In addition to the $t$ test for these parameters, the $t$ test was also carried out on the radiation rate data, and the obtained results were $S i g=0.815$. It means that the mean data was not significantly different. The distribution of water, soil and plant radioactivity data at several sampling locations resulting from optimization is the same as the distribution of radioactivity data at all sampling locations. Based on the results of this study, It can be recommended that the location of the environmental radioactivity sampling in radius of 100 - $1500 \mathrm{~m}$ from the reactor center.
\end{abstract}

Keywords: Sampling points, radioactivity, environment, wind direction, statistics. 
Jurnal Iptek Nuklir Ganendra

Ganendra Journal of Nuclear Science and Technology

Vol. 21 No.2, Juli-2021: 93-106

\section{PENDAHULUAN}

Kawasan Nuklir Yogyakarta (KNY) memiliki reaktor nuklir yang dinamakan Reaktor Kartini dengan daya $100 \mathrm{~kW}$. Dalam pengoperasian suatu reaktor nuklir terdapat potensi penyebaran zat radioaktif ke lingkungan [1]. Sesuai dengan Peraturan Pemerintah RI No. 33 Tahun 2007 tentang Keselamatan Radiasi Pengion dan Keamanan Sumber Radioaktif dan Peraturan Kepala BAPETEN No.7 Tahun 2013 tentang Nilai Batas Radioaktivitas Lingkungan, Pemegang ljin (PI) wajib melaksanakan pemantauan radioaktivitas lingkungan di luar instalasi secara rutin. Pemantauan radioaktivitas lingkungan dilaksanakan secara berkala untuk memastikan proteksi radiasi bagi anggota masyarakat yang tinggal di sekitar instalasi nuklir [2].

Pemantauan radioaktivitas lingkungan di sekitar reaktor Kartini dilakukan sekali dalam sebulan. Dalam pemantauan radioaktivitas ini, data radioaktivitas air, udara, tanah, tanaman dan jatuhan diambil di beberapa lokasi titik sampel sesuai dengan dokumen Rencana Pengelolaan Lingkungan (RKL) dan Rencana Pemantauan Lingkungan (RPL) PSTA-BATAN Yogyakarta.

Pada tahun 1983 lokasi pengambilan sampel berjumlah 36 titik, yang berada pada radius $100 \mathrm{~m}-5000 \mathrm{~m}$ sesuai dengan dokumen AMDAL Reaktor Kartini [3]. Namun sejak tahun 2005 jumlah lokasi pengambilan sampel dikurangi menjadi hanya 18 titik. Rencana pemantauan lingkungan reaktor Kartini telah mengalami beberapa kali perubahan yaitu pada Tahun 2007 dan 2009 namun jumlah lokasi sampling tetap sebanyak 18 titik untuk air, 17 titik untuk tanah dan tanaman pada radius sampai dengan 5000 meter. Pada tahun 2016, dilakukan penambahan 1 titik sampling air atas rekomendasi dari BAPETEN [3].

Reaktor Kartini memiliki daya nominal $100 \mathrm{kWatt}$ [4], lebih kecil dari reaktor Bandung dengan daya 2 Mwatt [5] dan Reaktor Siwabessy Serpong dengan daya 30 Mwatt [6]. Pemantauan radioaktivitas lingkungan di reaktor Bandung hanya mencapai radius $2 \mathrm{~km}$ [7] sedangkan di reaktor Serpong mencapai radius $5 \mathrm{~km}$ [8]. Salah satu Pembangkit Listrik Tenaga Nuklir (PLTN) di Rusia melakukan pemantauan radioaktivitas udara pada jarak 1,4 -5,4 $\mathrm{km}$ [9] dan fall out pada jarak $0,7 \mathrm{~km}-2,2 \mathrm{~km}$ [10]. Dengan mempertimbangkan daya operasi reaktor, maka pemantauan lingkungan di reaktor Kartini yang mencapai $5 \mathrm{~km}$ tentu tidak efisien. Oleh karena itu penentuan lokasi sampling pada radius $5 \mathrm{~km}$ perlu untuk ditinjau kembali.

Pemantauan radioaktivitas lingkungan di sekitar KNY sampai dengan radius $5000 \mathrm{~m}$, merupakan jarak yang cukup jauh dari pusat reaktor Kartini. Bila dibandingkan dengan reaktor yang ada di Bandung dan Serpong yang berkapasitas daya nya lebih besar [5,6], pemantauan lingkungan di sekitar KNY sampai dengan radius $5000 \mathrm{~m}$ dianggap kurang efisien sehingga perlu ada upaya optimalisasi radius pemantauan lingkungan. Hal ini juga didukung dari hasil pemantauan radioaktivitas gross beta lingkungan di sekitar KNY yang telah dilaksanakan dari tahun 1984 sampai dengan sekarang, tidak ada yang melebihi data radioaktivitas lingkungan rona awal sebelum reaktor beroperasi (tahun 1983) [11]. Bahkan pola nilai radioaktivitas yang terukur pada beberapa titik tertentu tidak ditemukan adanya peningkatan dan masih dalam rentang latar.

Dari dokumen (Laporan Analisis Keselamatan) LAK reaktor Kartini diperkirakan bahwa ketika reaktor mengalami kecelakaan 1 (satu) bahan bakar pecah karena adanya kegagalan pada saat proses loading-unloading maka dosis radiasi tertinggi akibat terdispersinya beberapa radionuklida ke lingkungan adalah sebesar 4,52 × 10${ }^{10} \mathrm{mSv}$ pada jarak 110 meter [12]. Daerah terdampak akibat kecelakaan terparah hanya sampai radius 110 meter, sehingga bila reaktor Kartini beroperasi dalam kondisi normal jarak dispersi radionuklida kurang dari 110 meter. Hasil simulasi dengan menggunakan perangkat lunak Hotspot diperoleh bahwa daerah safety perimeter pada saat terjadi kecelakaan di RSG-GAS Serpong pada daya $15 \mathrm{MW}$ adalah radius antara 500-1000 m dari stack reactor [13]. Terjadinya kerusakan bahan bakar pada reaktor TRIGA MARK II PUSPATI Malaysia diperkirakan dapat menyebabkan dampak yang signifikan terhadap lingkungan dan manusia di sekitarnya pada radius $300 \mathrm{~m}$ dari pusat reaktor, dengan laju dosis diperkirakan sebesar 1,326 mSv/tahun [14].

Menurut Peraturan Kepala BAPETEN No. 1 Tahun 2010 tentang Kesiapsiagaan dan Penanggulangan Kedaruratan Nuklir, bahaya radiologi reaktor dengan daya lebih kecil dari $2 \mathrm{MWt}$ termasuk kategori III. Bahaya radiologi kategori III adalah untuk instalasi atau fasilitas dengan potensi bahaya tidak memberikan dampak di luar tapak tetapi berpotensi memberikan efek deterministik di dalam tapak. Oleh karena itu pemantauan lingkungan di sekitar reaktor Kartini sampai dengan radius $5 \mathrm{~km}$ adalah berlebihan.

Berdasarkan uraian di atas dan permasalahan sumber daya dari tahun ke tahun yang semakin terbatas maka diperlukan optimalisasi pengurangan jumlah lokasi sampling radioaktivitas lingkungan di sekitar KNY, untuk meninjau dan mengetahui apakah jarak dan jumlah titik sampling yang ada di dokumen RKL dan RPL tahun 2016 No 001.1/KN 04 04/STA 5.1 ada kemungkinan untuk dikurangi tanpa mempengaruhi hasil pemantauan lingkungan 
yang dilakukan selama ini. Tujuan dari kajian ini adalah untuk menentukan kemungkinan dilakukannya pengurangan titik lokasi sampling air, tanah dan tanaman di lingkungan sekitar reaktor Kartini. Hasil dari kajian ini diharapkan dapat digunakan sebagai dasar revisi dokumen RKL dan RPL PSTA.

Penyebaran zat radioaktif salah satunya dipengaruhi oleh arah angin $[13,15]$. Arah angin adalah arah dari mana angin berhembus. Angin akan membawa zat radioaktif dari titik sumber menuju ke suatu tempat. Dengan mempertimbangkan arah angin dominan di daerah tersebut, maka lokasi sampling yang berada di sekitar arah angin dominan, arah dari mana datangnya angin berasal, akan dihilangkan. Pengurangan jumlah lokasi sampling diharapkan tidak mempengaruhi secara signifikan hasil rerata radioaktivitas lingkungan dengan jumlah lokasi sampling selama ini. Evaluasi data dilakukan secara statistik dengan menggunakan uji beda t dan berdasarkan sebaran data radioaktivitas air, tanah dan tanaman.

\section{METODOLOGI}

Pada kajian ini digunakan data arah angin tahun 2012 -2017 yang diperoleh dari Stasiun Meteorologi Adi Sucipto, Yogyakarta. Untuk pembuatan cakra angin digunakan software WRPlot (WindRose Plot) versi 7.0.0. Daftar lokasi sampling ditampilkan pada Tabel 1. Data radioaktivitas air, tanah dan tanaman sekitar KNY Tahun 2009 - 2018, data laju dosis radiasi lingkungan Tahun 2017 -2018. Pengolah data secara statistik digunakan software PSPP versi 3. Pengujian dilakukan dengan menggunakan uji dua sisi dengan tingkat signifikansi $\alpha=5 \%$ $=0,05$ (untuk tingkat kepercayaan $95 \%$ ). Bila nilai siqnificant (siq) atau $p<0,05$ maka ada beda signifikan [16]. Bagan alir metodologi penelitian ditampilkan pada Gambar 1.

Tabel 1. Daftar lokasi pengambilan sampel [3].

\begin{tabular}{|c|c|c|c|c|c|}
\hline No & Lokasi & Lintang Selatan & Bujur Timur & Jenis Sampel & Keterangan \\
\hline 1 & KNY-100-1 & $7^{\circ} 46^{\prime} 41.1852^{\prime \prime}$ & $110^{\circ} 24^{\prime} 46.9512^{\prime \prime}$ & Air permukaan & Kolam terpadu \\
\hline 2 & KNY-100-2 & $7^{\circ} 46^{\prime} 37.9200^{\prime \prime}$ & $110^{\circ} 24^{\prime} 47.2200^{\prime \prime}$ & $\begin{array}{l}\text { Tanaman, sedimen dan air } \\
\text { permukaan }\end{array}$ & Utara Gd.Bengkel \\
\hline 3 & KNY-100-3 & $7^{0} 46^{\prime} 42.1572^{\prime \prime}$ & $110^{\circ} 24^{\prime} 46.2996^{\prime \prime}$ & Air permukaan & Outlet kolam terpadu \\
\hline 4 & KNY-200-1 & $7^{0} 46^{\prime} 43.8312^{\prime \prime}$ & $110^{\circ} 24^{\prime} 50.2308^{\prime \prime}$ & Tanah, tanaman dan air tanah & Komplek BATAN \\
\hline 5 & KNY-500-1 & $7^{0} 46^{\prime} 49.9152^{\prime \prime}$ & $110^{\circ} 24^{\prime} 44.0604^{\prime \prime}$ & $\begin{array}{l}\text { Tanaman, sedimen, dan air } \\
\text { permukaan }\end{array}$ & Desa Ngentak \\
\hline 6 & KNY-500-2 & $7^{\circ} 46^{\prime} 40.2708^{\prime \prime}$ & $110^{\circ} 24^{\prime} 39.9312^{\prime \prime}$ & Tanah, tanaman dan air tanah & Desa Kledokan \\
\hline 7 & KNY-500-3 & $7^{0} 46^{\prime} 27.8472^{\prime \prime}$ & $110^{\circ} 24^{\prime} 50.8428^{\prime \prime}$ & Tanah, tanaman dan air tanah & Yadara \\
\hline 8 & KNY-1000-1 & $7^{\circ} 47^{\prime} 0.2112^{\prime \prime}$ & $110^{\circ} 25^{\prime} 0.6924^{\prime \prime}$ & Tanah, tanaman dan air tanah & Jl.Raya Yogya -Solo \\
\hline 9 & KNY-1000-2 & $7^{\circ} 46^{\prime} 38.2764^{\prime \prime}$ & $110^{\circ} 24^{\prime} 24.6060^{\prime \prime}$ & Tanah, tanaman dan air tanah & Desa Mundusaren \\
\hline 10 & KNY-1000-3 & $7^{\circ} 46^{\prime} 24.6108^{\prime \prime}$ & $110^{\circ} 24^{\prime} 29.6424^{\prime \prime}$ & Tanah, tanaman dan air tanah & Desa Puren \\
\hline 11 & KNY-1000-4 & $7^{0} 46^{\prime} 28.8624^{\prime \prime}$ & $110^{\circ} 25^{\prime} 17.9076^{\prime \prime}$ & Tanah, tanaman dan air tanah & Desa Magowoharjo \\
\hline 12 & KNY-1500-1 & $7^{\circ} 47^{\prime} 12.9120^{\prime \prime}$ & $110^{\circ} 24^{\prime} 46.2996^{\prime \prime}$ & Tanah, tanaman dan air tanah & Desa Janti \\
\hline 13 & KNY-1500-2 & $7^{0} 46^{\prime} 12.9108^{\prime \prime}$ & $110^{\circ} 24^{\prime} 20.5020^{\prime \prime}$ & Tanah, tanaman dan air tanah & Perumnas Seturan \\
\hline 14 & KNY-1500-3 & $7^{0} 46^{\prime} 41.7576^{\prime \prime}$ & $110^{\circ} 25^{\prime} 32.1312^{\prime \prime}$ & Tanah, tanaman dan air tanah & Magowoharjo \\
\hline 15 & KNY-1500-4 & $7^{\circ} 46^{\prime} 5.3688^{\prime \prime}$ & $110^{\circ} 25^{\prime} 3.4932^{\prime \prime}$ & $\begin{array}{l}\text { Tanah, tanaman dan air } \\
\text { permukaan }\end{array}$ & JI.Selokan Mataram \\
\hline 16 & KNY-5000-1 & $7^{\circ} 44^{\prime} 58.9848^{\prime \prime}$ & $110^{\circ} 23^{\prime} 8.6858^{\prime \prime}$ & Tanah, tanaman dan air tanah & J.Kaliurang Km 6,5 \\
\hline 17 & KNY-5000-2 & $7^{0} 44^{\prime} 31.2000^{\prime \prime}$ & $110^{\circ} 25^{\prime} 49.9620^{\prime \prime}$ & Tanah, tanaman dan air tanah & Desa Widomartani \\
\hline 18 & KNY-5000-3 & $7^{\circ} 47^{\prime} 49.4448^{\prime \prime}$ & $110^{\circ} 26^{\prime} 42.7596^{\prime \prime}$ & Tanah, tanaman dan air tanah & Desa Berbah \\
\hline 19 & KNY-5000-4 & $7^{\circ} 48^{\prime} 34.9524^{\prime \prime}$ & $110^{\circ} 23^{\prime} 14.8668^{\prime \prime}$ & Tanah, tanaman dan air tanah & $\begin{array}{l}\text { Depan Kantor Camat } \\
\text { Umbulharjo }\end{array}$ \\
\hline
\end{tabular}




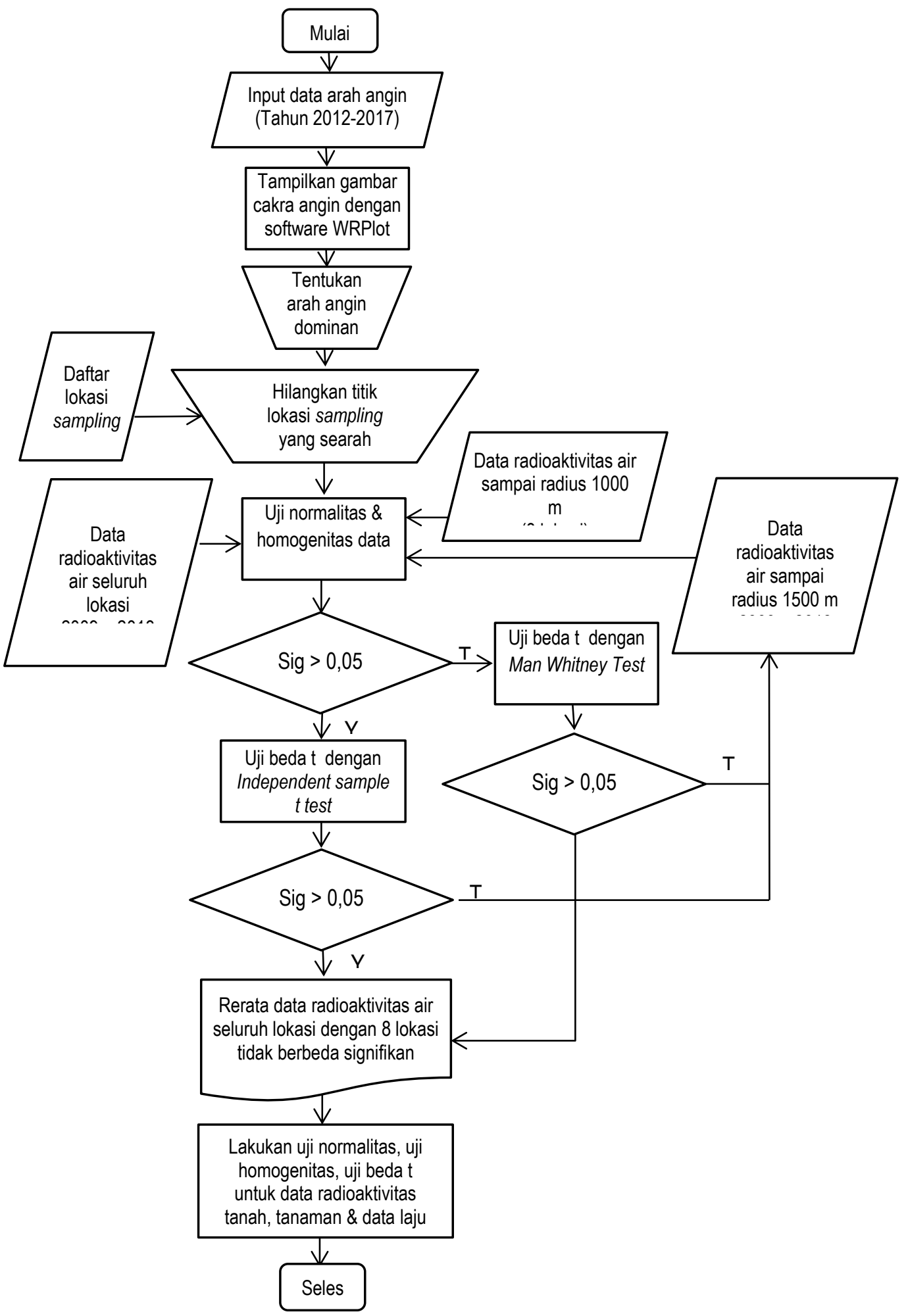

Gambar 1. Bagan alir metodologi penelitian.

Simulasi pertama ditetapkan radius sampling sampai $1000 \mathrm{~m}$ untuk sampel air, sehingga jumlah lokasi sampling menjadi 8 titik. Selanjutnya dilakukan evaluasi data, dengan menguji perbedaan antara rerata data radioaktivitas air lingkungan untuk seluruh lokasi sampling (19 titik) dan rerata data radioaktivitas air bila hanya 
beberapa lokasi sampling yang tetap dipertahankan (8 titik). Evaluasi data dilakukan dengan uji beda t yaitu Independent sampel t-test atau Man Whitney $U$ test. Apabila hasil evaluasi memberikan nilai sig < 0,05; hal ini menunjukkan bahwa ada perbedaan signifikan antara rerata data radioaktivitas air pada seluruh titik sampling dan rerata data radioaktivitas air pada 8 titik sampling yang diajukan, maka dilakukan uji coba dengan menggunakan skenario yang lain yaitu dengan menambah jumlah lokasi sampling menjadi 9 titik, dengan radius sampling sampai $1000 \mathrm{~m}$. Apabila diperoleh nilai sig < 0,05 maka dilakukan uji coba dengan data radioaktivitas pada lokasi sampling yang lain dengan radius sampling sampai $1500 \mathrm{~m}$. Apabila hasil evaluasi diperoleh nilai sig > 0,05; hal ini menunjukkan bahwa tidak terjadi perbedaan signifikan antara rerata data radioaktivitas air pada seluruh lokasi sampling dan rerata data radioaktivitas air pada 9 titik sampling yang diajukan maka simulasi dilanjutkan dengan melakukan simulasi yang sama pada data radioaktivitas tanah dan tanaman serta laju dosis radiasi.

\section{HASIL DAN PEMBAHASAN}

Pemantauan radioaktivitas lingkungan pada sampel air, tanah dan tanaman di sekitar KNY dilakukan secara rutin setiap bulan dari sebelum reaktor Kartini beroperasi sampai sekarang. Sebaran data radioaktivitas air, tanah dan tanaman selama periode 10 tahun (2009 - 2018) ditampilkan pada Gambar 2.

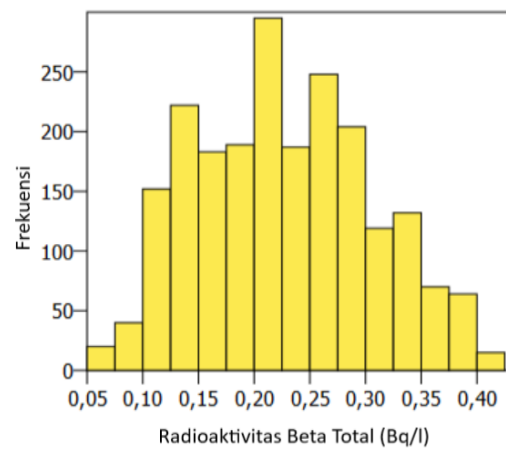

(a). Air

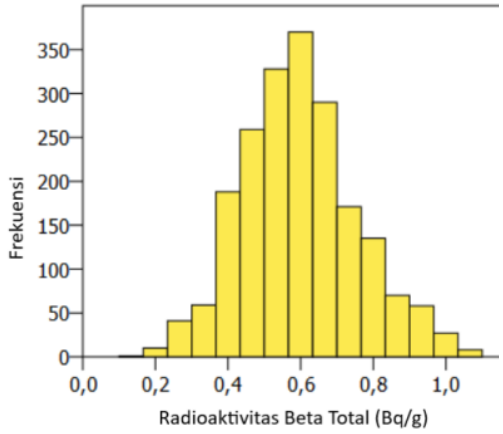

(b). Tanah

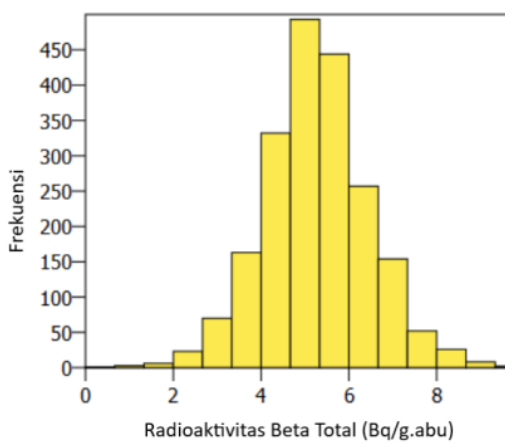

(c). Tanaman

Gambar 2. Sebaran Data Radioaktivitas (a) Air, (b) Tanah dan (c) Tanaman Tahun 2009-2018.

Tabel 2. Statistik Deskriptif Data Radioaktivitas Air, Tanah dan Tanaman Tahun 2009-2018.

\begin{tabular}{lllll}
\hline $\begin{array}{c}\text { Jenis Radioaktivitas } \\
\text { (Satuan) }\end{array}$ & Nilai rata - rata & Nilai Standar Deviasi & Nilai Minimum & Nilai Maksimum \\
\hline Air (Bq/l) & 0,23 & 0,08 & 0,05 & 0,40 \\
Tanah (Bq/g) & 0,60 & 0,16 & 0,10 & 1,07 \\
Tanaman (Bq/g.abu) & 5,26 & 1,20 & 0,20 & 9,75 \\
\hline
\end{tabular}

Data radioaktivitas air tahun 2009 - 2018 memiliki nilai rata - rata 0,23 Bq/l dengan rentang data antara $(0,05-0,40) \mathrm{Bq} / \mathrm{l}$. Data ini masih berada di rentang data rona awal untuk radioaktivitas air yaitu antara $(0,007-$ $1,184) \mathrm{Bq} / \mathrm{l}[3]$. Sebaran data tidak terdistribusi normal (gausian), cenderung condong ke kiri, dengan sebagian besar data bernilai $\leq 0,23 \mathrm{~Bq} / \mathrm{l}$. Sedangkan untuk data radioaktivitas tanah berada pada rentang $(0,10-1,07) \mathrm{Bq} / \mathrm{g}$ dan memiliki nilai rata- rata $0,60 \mathrm{~Bq} / \mathrm{g}$ dengan sebaran data cenderung condong ke kiri. Data tidak terdistribusi normal dengan $54 \%$ data berada di sebelah kiri $(\leq 0,60 \mathrm{~Bq} / \mathrm{g})$. Data rona awal untuk radioaktivitas tanah sebesar $(0,185-1,087) \mathrm{Bq} / \mathrm{g}[3]$. Bila dibandingkan dengan dara rona awal ini, data radioaktivitas tanah tahun 2009 - 2018 masih berada dalam rentang data rona awal. Tanaman (rumput) memiliki kandungan radioaktivitas beta total yang lebih tinggi dibandingkan dengan air dan tanah. Tanaman dapat mengakumulasi bahan radioaktif yang terdapat di air maupun di tanah sebagai tempat tumbuhnya [17]. Nilai rata-rata radioaktivitas tanah sebesar $5,26 \mathrm{~Bq} / \mathrm{g}$.abu, dengan rentang data antara $(0,20-9,75)$ Bq/g.abu. Nilai ini masih berada di rentang nilai rona awal sebelum reaktor Kartini beroperasi yaitu $(0,478-10,931)$ Bq/g.abu [3]. Sebaran data tidak terdistribusi normal, data lebih condong ke kiri. 
Jurnal Iptek Nuklir Ganendra

Ganendra Journal of Nuclear Science and Technology

Vol. 21 No.2, Juli-2021: 93-106

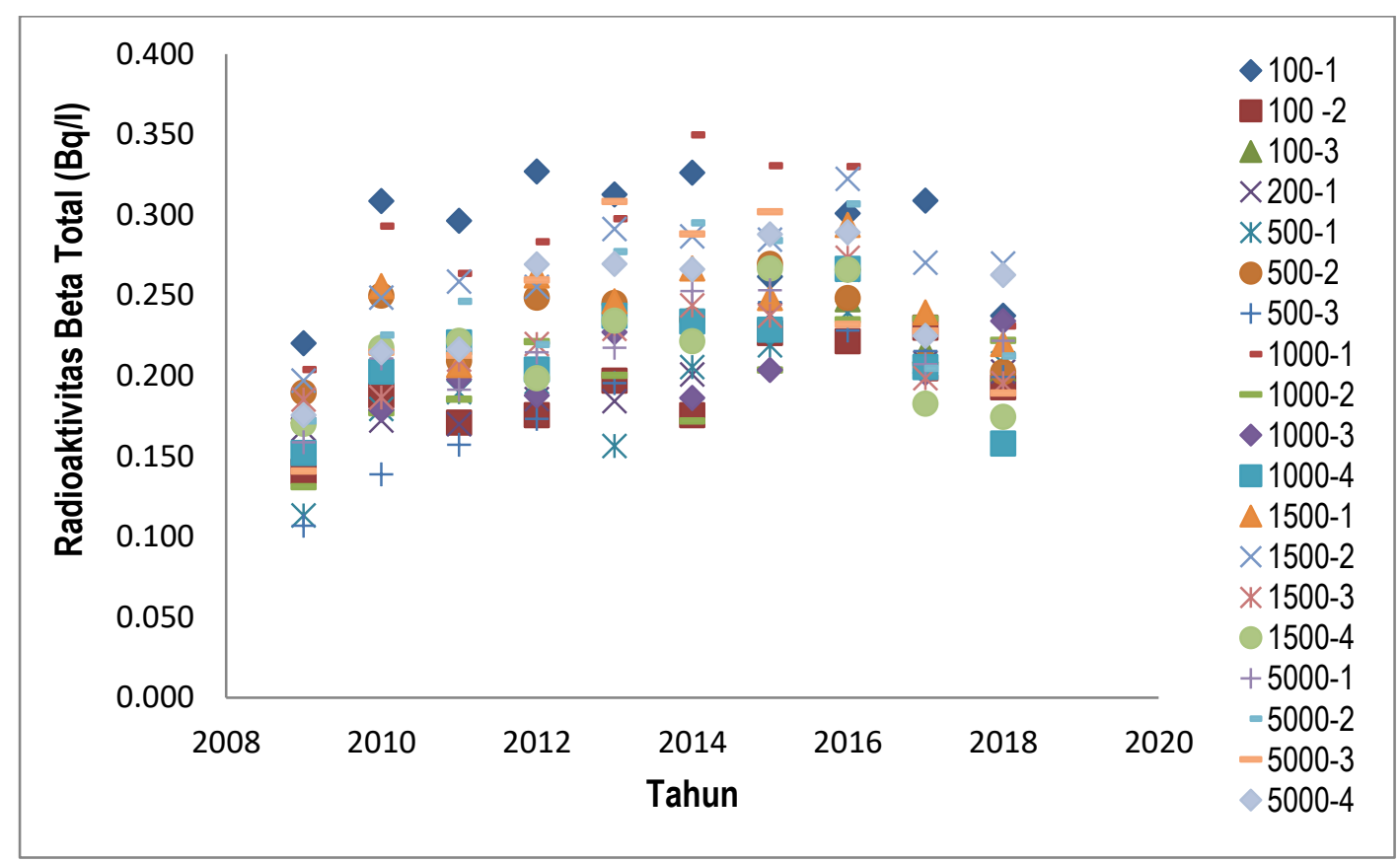

Gambar 3. Data Radioaktivitas Air Tahun 2009 - 2018 pada Semua Lokasi Sampling (data rata-rata).

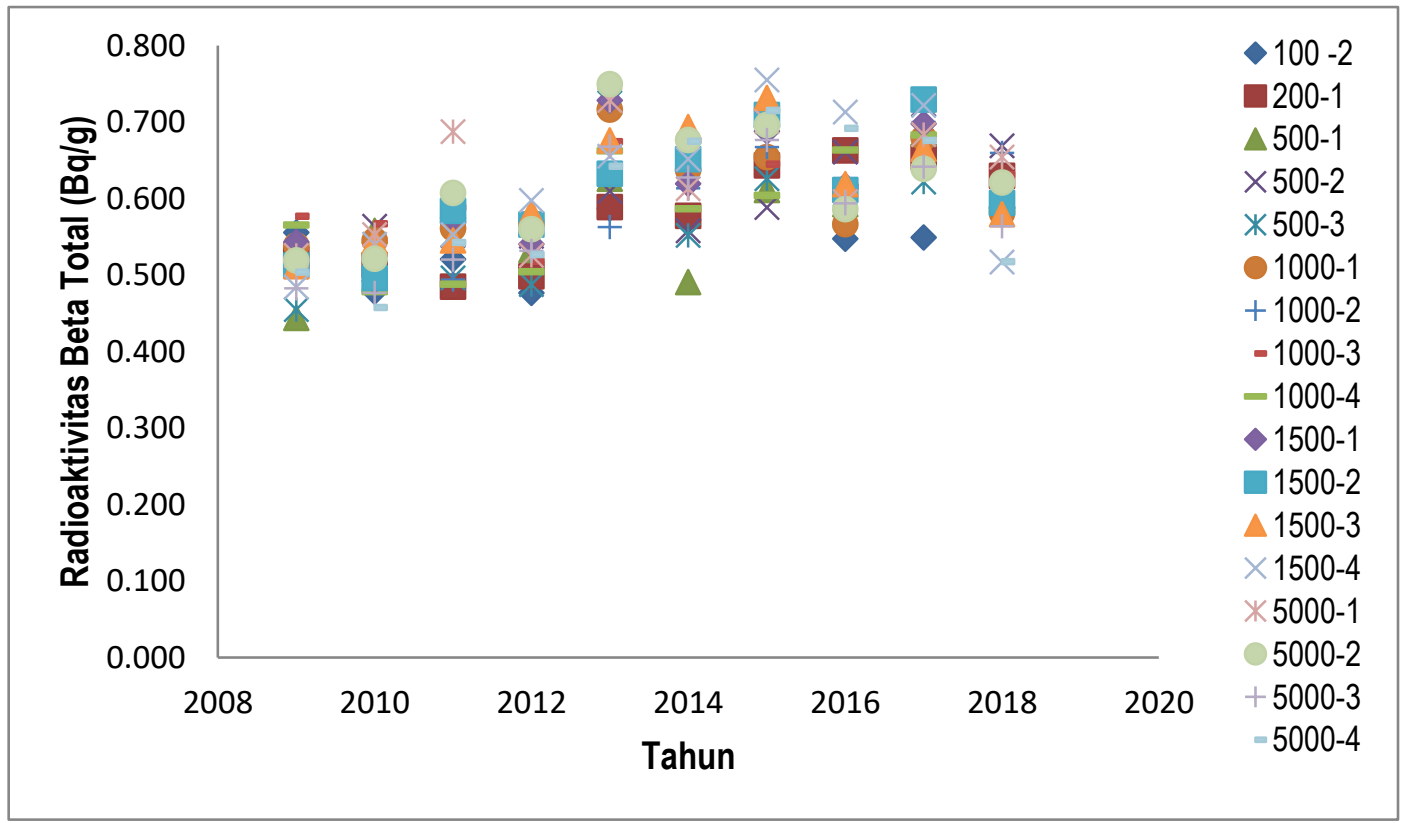

Gambar 4. Data Radioaktivitas Tanah Tahun 2009 - 2018 pada Semua Lokasi Sampling (data rata-rata).

Pada Gambar 3, 4 dan 5 menunjukkan hasil pengukuran tingkat radioaktivitas air, tanah dan tanaman tidak dipengaruhi oleh jarak lokasi sampling. Semakin jauh dari pusat reaktor Kartini (kode lokasi 5000) tidak memberikan hasil tingkat radioaktivitas yang semakin kecil, begitu pula sebaliknya semakin dekat dari reaktor (kode lokasi 100) tidak berarti memberikan hasil pengukuran radioaktivitas yang lebih besar dibandingkan jarak yang lebih jauh dari reaktor. Hasil pengukuran tingkat radioaktivitas bersifat acak. Radioaktivitas beta total yang terukur di lingkungan ini berasal dari alam, bukan berasal dari pengoperasian reaktor Kartini. Tren tingkat radioaktivitas dari tahun 2009 sampai tahun 2018 juga bersifat acak baik untuk radioaktivitas air, tanah dan tanaman, kadang di tahun tertentu naik dan kadang mengalami penurunan tingkat radioaktivitas. 


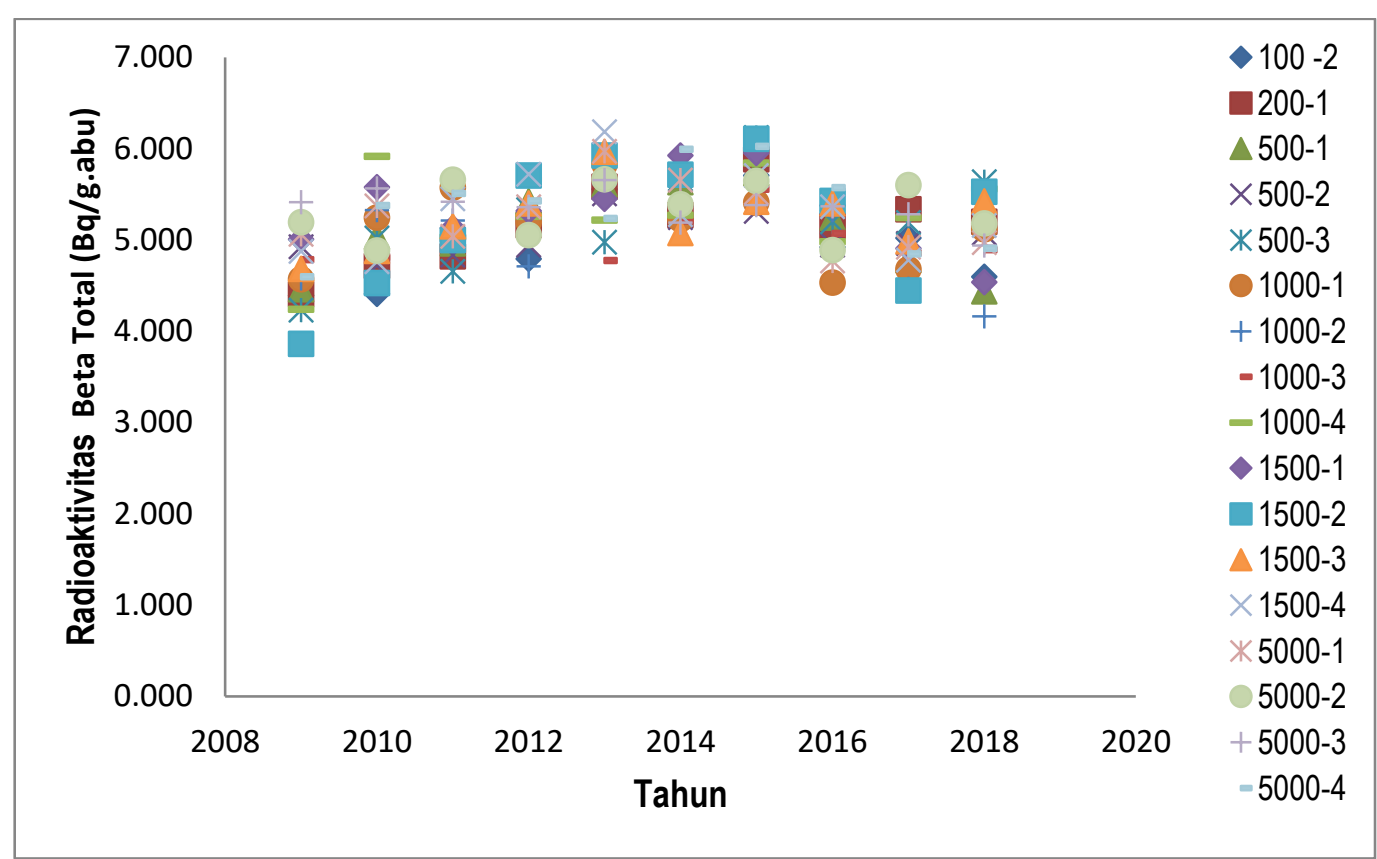

Gambar 5. Data Radioaktivitas Tanaman Tahun 2009 - 2018 pada Semua Lokasi Sampling (data rata-rata).

Penentuan arah angin dominan menggunakan data arah angin Tahun 2012-2017 dari stasiun meteorogi terdekat dari lokasi Reaktor Kartini yaitu Stasiun Meteorologi Bandara Adi Sucipto. Dari data arah angin yang diolah menggunakan software WRPlot diperoleh cakra arah angin tahunan sebagaimana ditunjukkan pada Gambar 6 . Berdasarkan data cakra arah angin tahun 2012, 2013, 2014, 2015 dan 2017, arah angin dominan berasal dari arah Barat Daya dan Selatan. Arah angin dominan di tahun 2016 berbeda dengan tahun lainnya, hal ini terjadi salah satunya karena ada fenomena La Nina di tahun tersebut. Peristiwa La Nina dapat mempengaruhi arah angin di Indonesia. Pada bulan Agustus - Desember 2016 terjadi anomali angin zonal dan angin meridional di wilayah Indonesia. Angin meridional dominan bernilai negatif yaitu angin bergerak ke selatan [18]. Selama periode 6 tahun ini hanya di tahun 2016 yang memiliki arah angin dominan yang berbeda sehingga arah angin dominan adalah arah dari Barat Daya dan Selatan. Hal ini didukung dengan hasil pengolahan data arah angin tahun 2012 - 2017, ditampilkan pada Gambar 7, menunjukkan angin dominan berasal dari arah Barat Daya dan Selatan.

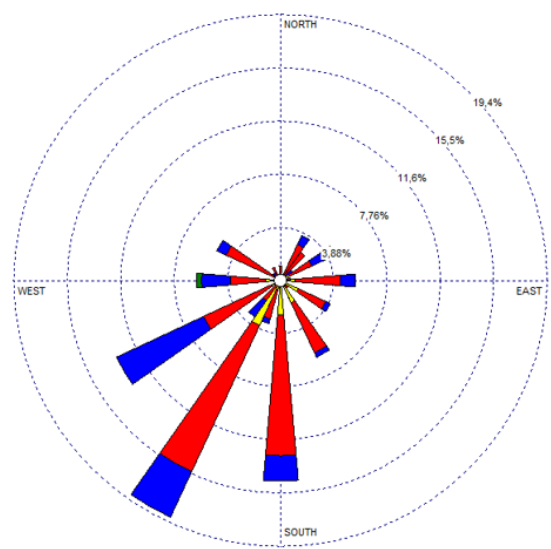

(a) Tahun 2012
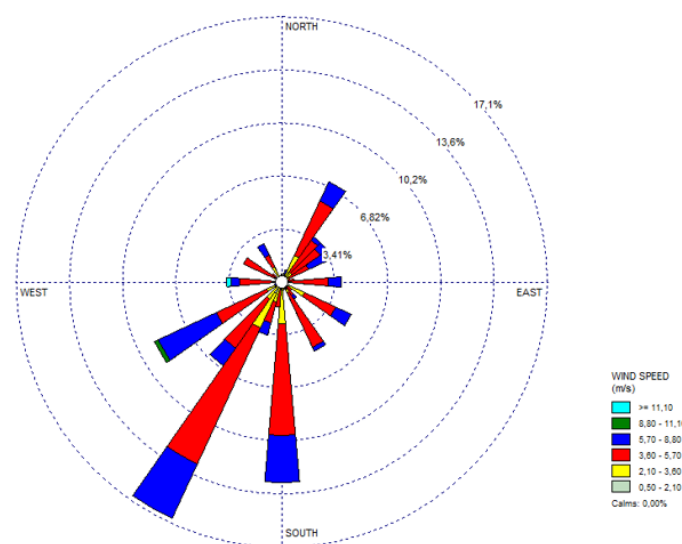

(b). Tahun 2013 


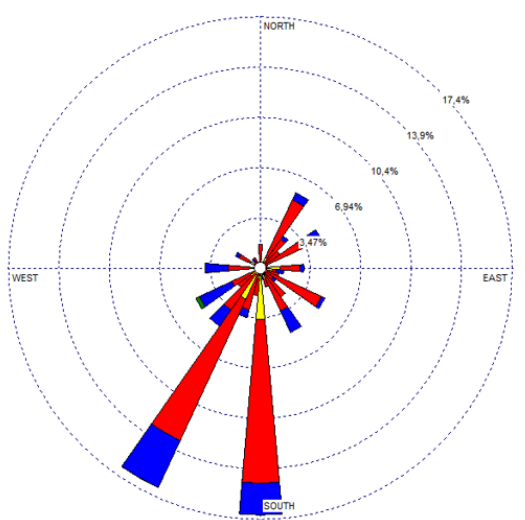

(c). Tahun 2014

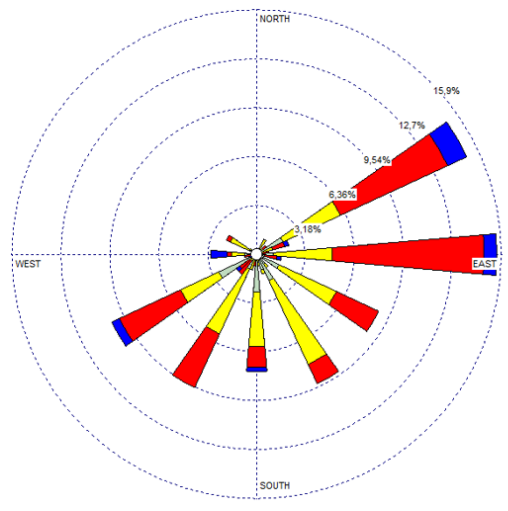

(e). Tahun 2016
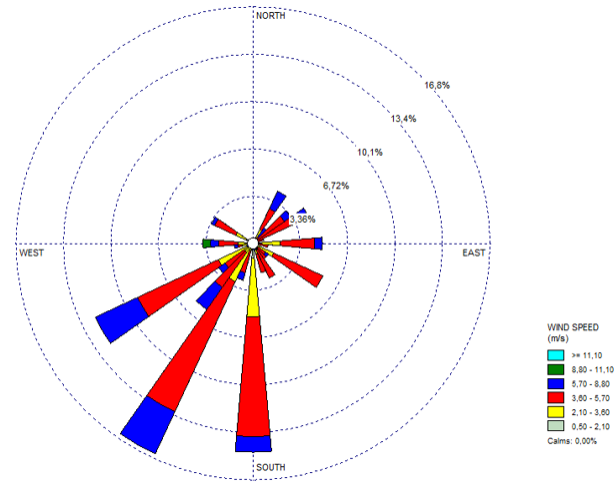

(d). Tahun 2015

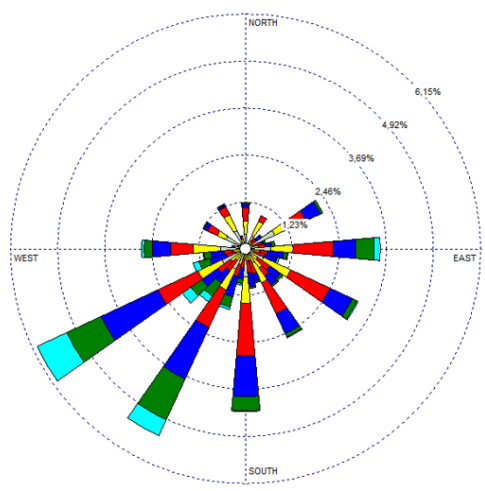

(f). Tahun 2017

Gambar 6. Cakra angin Tahun (a) 2012, (b) 2013, (c) 2014, (d) 2015, (e) 2016 dan (f) 2017 (24 Jam).

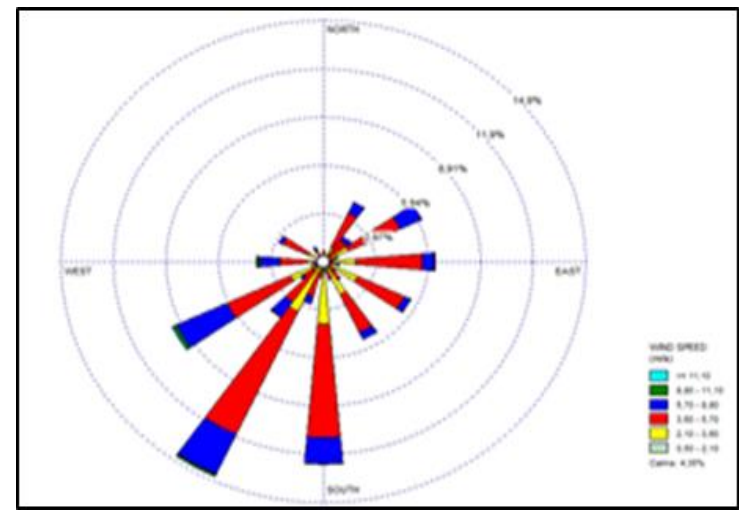

Gambar 7. Cakra angin Tahun 2012 - 2017 (24 Jam).

Dari Gambar 7 dapat dilihat bahwa arah angin dominan berasal dari Barat Daya dan Selatan, untuk itu lokasi sampling yang berada di sebelah Barat Daya dan Selatan, terletak pada range $135^{\circ}-292,5^{\circ}$ dapat dihilangkan. Lokasi sampling sesuai dokumen RKL dan RPL PSTA tahun 2016 dapat dilihat pada Gambar 8. 


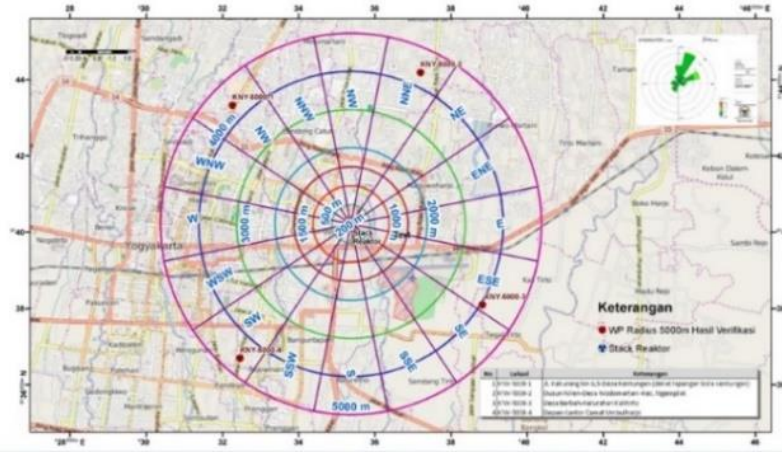

Radius 5000 meter

(Semua lokasi KNY-5000 sebanyak 4 titik akan dihilangkan)

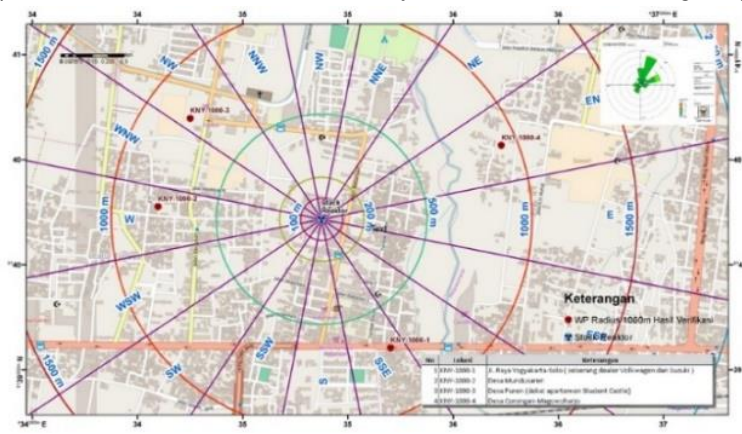

Radius 1000 meter

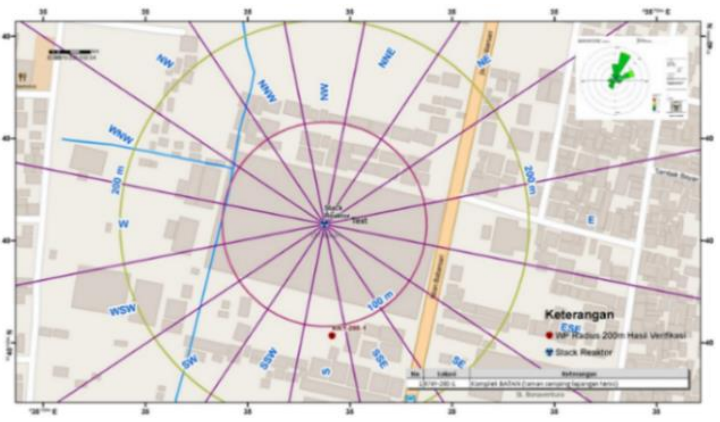

Radius 200 meter

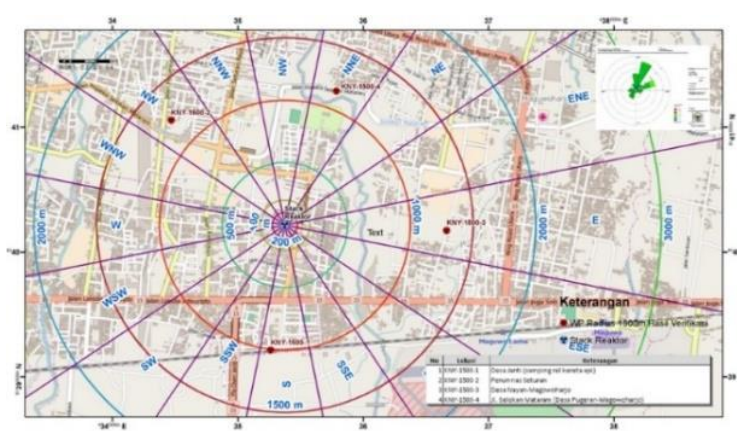

Radius 1500 meter

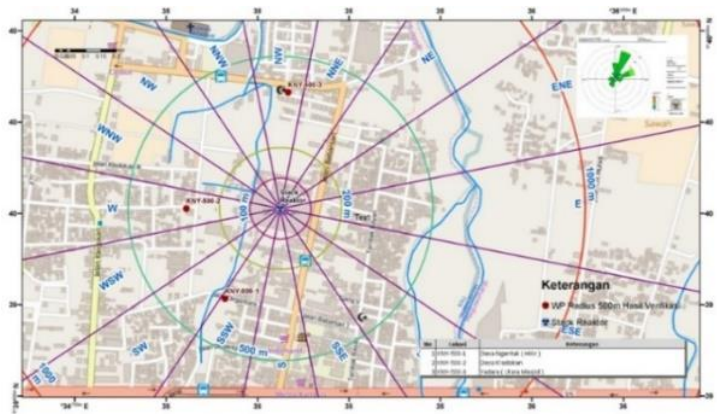

Radius 500 meter

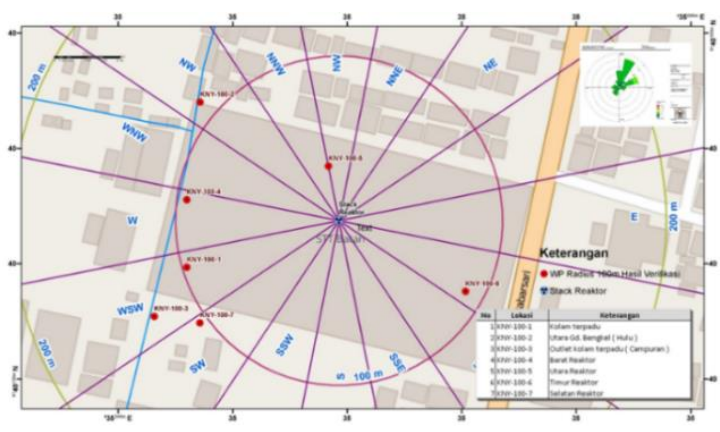

Radius 100 meter

(Semua lokasi tetap dipertahankan)

Gambar 8. Titik- titik sampling radioaktivitas lingkungan KNY radius 100 s.d. 5000 meter.

Dalam kajian ini digunakan pendekatan kuantitatif dengan pengujian hipotesis. Pengujian hipotesis dilakukan dengan melakukan uji independen (Independent sample $t$-Test). Independent sample $t$-Test adalah uji yang digunakan untuk menentukan apakah dua sampel yang tidak berhubungan memiliki rata-rata yang berbeda. Jadi tujuan metode statistik ini adalah membandingkan rata-rata dua grup yang tidak berhubungan satu dengan yang lain. Pengujian ini membandingkan antara rerata data radioaktivitas lingkungan pada seluruh lokasi sampling dan rerata data radioaktivitas lingkungan pada beberapa lokasi sampling yang tetap dipertahankan.

Analisis diawali dengan uji normalitas terhadap data yang digunakan untuk mendeteksi normalitasnya dengan metode Kolmogorov-Smirnov test. Setelah dilakukan uji normalitas, maka selanjutnya dilakukan analisis data dengan uji $t$ independen. Metode Kolmogorov-Smirnov test dipilih karena merupakan metode pengujian normalitas yang umum dan banyak digunakan untuk menguji normalitas data $[19,20]$. Tujuan pengujian ini adalah untuk mengetahui apakah sampel yang digunakan dalam kajian ini adalah berdistribusi normal atau tidak. Sampel berdistribusi normal apabila Asymptotic sig lebih besar dari tingkat keyakinan yang digunakan dalan pengujian, dalam hal ini adalah $95 \%$ atau a $5 \%$. Sebaliknya dikatakan tidak normal apabila Asymptotic sig lebih kecil dari tingkat keyakinan. Jika hasil menunjukkan sampel berdistribusi normal, uji beda yang akan digunakan dalam kajian ini adalah uji parametrik (Independent sampel $t$-Test). Jika sampel berdistribusi tidak normal, maka uji beda yang digunakan dalam kajian ini adalah uji non parametrik yaitu Man Whitney $U$ test $[21,22,23]$. 
Jurnal Iptek Nuklir Ganendra

Ganendra Journal of Nuclear Science and Technology

Vol. 21 No.2, Juli-2021: 93-106

Rencana pengurangan titik sampling (optimalisasi) dilakukan dengan menguji beberapa lokasi sampling yang tetap dipertahankan melalui beberapa percobaan. Uji coba dilakukan sampai didapatkan hasil uji rerata radioaktivitas air, tanah, tanaman pada lokasi seluruh sampling yang dilakukan selama ini dibandingkan dengan beberapa lokasi yang dipertahankan, tidak ada beda signifikan. Hasil uji optimalisasi pengurangan titik sampling dapat dilihat pada Tabel 3 .

Tabel 3. Hasil pengujian optimalisasi titik sampling menggunakan uji beda t berdasarkan data radioaktivitas air.

\begin{tabular}{|c|c|c|c|c|c|}
\hline \multirow{3}{*}{$\begin{array}{l}\text { Percobaan } \\
\text { ke- }\end{array}$} & \multirow{3}{*}{$\begin{array}{c}\text { Lokasi yang } \\
\text { dipertahankan }\end{array}$} & \multirow{3}{*}{$\begin{array}{c}\text { Uji } \\
\text { Normalitas }\end{array}$} & \multicolumn{2}{|c|}{ Hasil Uji } & \\
\hline & & & Uji & \multicolumn{2}{|c|}{ Signifikan } \\
\hline & & & Homogenitas & $\begin{array}{c}\text { Independent } \\
\text { test }\end{array}$ & $\begin{array}{c}\text { Man-Whitney } \\
\text { Test }\end{array}$ \\
\hline 1. & $\begin{array}{l}100-1,100-2,100-3, \\
500-2,500-3, \\
1000-2,1000-3,1000-4 \\
\text { (8 lokasi sampling) }\end{array}$ & $\begin{array}{l}\text { Sig }=0,000 \\
\text { (data tidak } \\
\text { normal) }\end{array}$ & $\begin{array}{l}\text { Sig=0,763 } \\
\text { (data } \\
\text { homogen) }\end{array}$ & $\begin{array}{l}\text { Sig=0,002 } \\
\text { (data beda } \\
\text { signifikan) }\end{array}$ & $\begin{array}{l}\text { Sig=0,001 } \\
\text { (data beda } \\
\text { signifikan) }\end{array}$ \\
\hline 2. & $\begin{array}{l}100-1,100-2,100-3 \\
200-1 \\
500-2,500-3 \\
1000-2,1000-3,1000-4 \\
\text { (9 lokasi sampling) }\end{array}$ & $\begin{array}{l}\text { Sig }=0,000 \\
\text { (data tidak } \\
\text { normal) }\end{array}$ & $\begin{array}{l}\text { Sig }=0,719 \text { (data } \\
\text { homogen) }\end{array}$ & $\begin{array}{l}\text { Sig=0,000 } \\
\text { (data beda } \\
\text { signifikan) }\end{array}$ & $\begin{array}{l}\text { Sig=0,000 } \\
\text { (data beda } \\
\text { signifikan) }\end{array}$ \\
\hline 3. & $\begin{array}{l}100-1,100-2,100-3, \\
500-3, \\
1000-3,1000-4 \\
1500-2,1500-3,1500-4 \\
\text { (9 lokasi sampling) }\end{array}$ & $\begin{array}{l}\text { Sig }=0,000 \\
\text { (data tidak } \\
\text { normal) }\end{array}$ & $\begin{array}{l}\text { Sig=0,764 } \\
\text { (data } \\
\text { homogen) }\end{array}$ & $\begin{array}{l}\text { Sig=0,408 } \\
\text { (data tidak } \\
\text { beda } \\
\text { signifikan) }\end{array}$ & $\begin{array}{l}\text { Sig=0,423 } \\
\text { (data tidak beda } \\
\text { signifikan) }\end{array}$ \\
\hline
\end{tabular}

Tabel 4. Hasil pengujian percobaan optimalisasi titik sampling menggunakan uji beda t berdasarkan data radioaktivitas tanah \& tanaman.

\begin{tabular}{|c|c|c|c|c|c|}
\hline \multirow{3}{*}{$\begin{array}{l}\text { Percobaan } \\
\text { ke- }\end{array}$} & \multirow{3}{*}{$\begin{array}{l}\text { Lokasi yang } \\
\text { dipertahankan }\end{array}$} & \multicolumn{4}{|c|}{ Hasil Uji } \\
\hline & & \multirow{2}{*}{$\begin{array}{c}\text { Uji } \\
\text { Normalitas }\end{array}$} & \multirow{2}{*}{$\begin{array}{c}\text { Uji } \\
\text { Homogenitas }\end{array}$} & \multicolumn{2}{|c|}{ Uji Signifikan } \\
\hline & & & & $\begin{array}{l}\text { Independent } \\
\text { test }\end{array}$ & $\begin{array}{l}\text { Man-Whitney } \\
\text { Test }\end{array}$ \\
\hline $\begin{array}{l}4 . \\
\text { (TANAH) }\end{array}$ & $\begin{array}{l}100-2, \\
500-3, \\
1000-3,1000-4 \\
1500-2,1500-3,1500-4 \\
\text { (7 lokasi sampling) }\end{array}$ & $\begin{array}{l}\text { Sig=0 ,000 } \\
\text { (data tidak } \\
\text { normal) }\end{array}$ & $\begin{array}{l}\text { Sig=0,128 } \\
\text { (data } \\
\text { homogen) }\end{array}$ & $\begin{array}{l}\text { Sig }=0,873 \\
\text { (data tidak beda } \\
\text { signifikan) }\end{array}$ & $\begin{array}{l}\text { Sig }=0,764 \\
\text { (data tidak beda } \\
\text { signifikan) }\end{array}$ \\
\hline $\begin{array}{l}5 . \\
\text { (TANAMAN) }\end{array}$ & $\begin{array}{l}100-2, \\
500-3, \\
1000-3,1000-4 \\
1500-2,1500-3,1500-4 \\
\text { (7 lokasi sampling) }\end{array}$ & $\begin{array}{l}\text { Sig=0 }, 002 \\
\text { (data tidak } \\
\text { normal) }\end{array}$ & $\begin{array}{l}\text { Sig=0,792 } \\
\text { (data } \\
\text { homogen) }\end{array}$ & $\begin{array}{l}\text { Sig }=0,837 \\
\text { (data tidak beda } \\
\text { signifikan) }\end{array}$ & $\begin{array}{l}\text { Sig=0,738 } \\
\text { (data tidak beda } \\
\text { signifikan) }\end{array}$ \\
\hline
\end{tabular}

Percobaan 1 dan 2 ditetapkan radius lokasi sampling sampai 1000 meter sehingga lokasi sampling pada radius $1500 \mathrm{~m}$ dan $5000 \mathrm{~m}$ dihilangkan. Dari kedua percobaan didapatkan data yang tidak terdistribusi normal (sig $<0,05)$ sehingga perlu dilakukan uji non parametrik yaitu Man-Whitney Test. Hasil uji beda t dengan Man-Whitney Test baik pada percobaan 1 dan 2 berbeda signifikan (sig < 0,05). Hal ini berarti, ada beda signifikan antara rerata radioaktivitas air pada seluruh lokasi sampling (radius $100 \mathrm{~m}$ s.d radius $5000 \mathrm{~m}$ ) dan rerata radioaktivitas air pada lokasi dari radius $100 \mathrm{~m}$ s.d. $1000 \mathrm{~m}$. Dengan demikian skenario 1 dan 2, penetapan radius sampling hanya sampai $1000 \mathrm{~m}$ tidak dapat diterapkan. Oleh karena itu radius sampling $1500 \mathrm{~m}$ perlu tetap dipertahankan. Hasil uji lokasi sampling sampai radius $1500 \mathrm{~m}$ dapat dilihat pada Percobaan 3. Pada percobaan 3, dengan 9 lokasi sampling 
yang tetap dipertahankan didapatkan hasil tidak berbeda signifikan antara rerata radioaktivitas air pada seluruh lokasi dan rerata radioaktivitas sampai radius $1500 \mathrm{~m}$. Oleh karena itu skenario ke-3 ini dapat diterapkan pada pengurangan lokasi sampling. Selain pada data radioaktivitas air, uji beda $t$ juga perlu dilakukan pada data radioaktivitas tanah dan tanaman (rumput). Hasil uji beda t pada tanah dan tanaman disajikan pada Tabel 4. Uji coba pada data radioaktivitas tanah dan tanaman memberikan hasil sig $>0,05$, sehingga tidak terdapat perbedaan yang signifikan antara rerata radioaktivitas seluruh lokasi sampling (17 titik) dan lokasi sampling sampai radius $1500 \mathrm{~m}$ (7 titik).

Sebaran data radioaktivitas air, tanah dan tanaman setelah dilakukan optimalisasi pengurangan titik sampling disajikan pada Gambar 9.



Gambar 9. Sebaran Data Radioaktivitas Air Setelah Optimalisasi Pengurangan Titik sampling.

Tabel 5. Statistik Deskriptif Data Radioaktivitas Air, Tanah dan Tanaman Setelah Optimalisasi Pengurangan Titik Sampling.

\begin{tabular}{lllll}
\hline $\begin{array}{l}\text { Jenis Radioaktivitas } \\
\text { (Satuan) }\end{array}$ & Nilai rata - rata & Nilai Standar Deviasi & Nilai Minimum & Nilai Maksimum \\
\hline Air (Bq/l) & 0,22 & 0,08 & 0,06 & 0,40 \\
Tanah (Bq/g) & 0,60 & 0,17 & 0,10 & 1,07 \\
Tanaman (Bq/g.abu) & 5,25 & 1,23 & 0,74 & 9,75 \\
\hline
\end{tabular}

Pada Gambar 9(a). dapat dilihat sebaran data radioaktivitas air setelah optimalisasi pengurangan titik sampling tidak terdistribusi normal, sebaran data cenderung condong ke kiri. Sebaran data radioaktivitas air ini cenderung sama dengan sebaran data pada radioaktivitas air tahun 2009 - 2018 seperti yang ditunjukkan pada Gambar 2(a). Nilai rata -rata radioaktivitas air pada Tabel 5. setelah optimalisasi tidak jauh berbeda dengan sebelum optimalisasi yaitu sebelum $0,23 \mathrm{~Bq} / \mathrm{l}$ dan $0,22 \mathrm{~Bq} / \mathrm{l}$ setelah optimalisasi. Sedangkan nilai standar deviasi baik sebelum optimalisasi dan setelah optimalisasi adalah sama yaitu sebesar $0,08 \mathrm{~Bq} / \mathrm{l}$. Sebelum optimalisasi, sebaran data radioativitas air berada pada rentang nilai $(0,05-0,40) \mathrm{Bq} / \mathrm{l}$, sedangkan setelah optimalisasi berada pada rentang nilai $(0,06-0,40) \mathrm{Bq} / \mathrm{l}$, rentang tersebut hampir sama, tidak ada beda nyata.

Pada Gambar 9(b), sebaran data radioaktivitas tanah setelah optimalisasi pengurangan titik sampling cenderung condong ke kiri. Sebaran data tidak terdistribusi normal. Hal ini sesuai dengan sebaran data sebelum optimalisasi, dimana data cenderung condong ke kiri dan tidak terdistribusi normal, seperti terlihat pada Gambar 2. Nilai rata -rata baik sebelum optimalisasi dan setelah optimalisasi tidak berubah yaitu tetap sebesar $0,60 \mathrm{~Bq} / \mathrm{g}$. Dan nilai standar deviasi tidak berbeda nyata, dimana standar deviasi data sebelum optimalisasi sebesar $0,16 \mathrm{~Bq} / \mathrm{g}$ sedangkan setelah penerapan optimalisasi diperkirakan sebesar $0,17 \mathrm{~Bq} / \mathrm{g}$. Sebaran data radioaktivitas tanah baik sebelum maupun setelah optimalisasi adalah sama yaitu berada pada rentang nilai $(0,10-1,07) \mathrm{Bq} / \mathrm{l}$

Sebaran data radioaktivitas tanaman pada Gambar 9(c) terlihat cenderung condong ke kiri. Hal ini sama seperti sebaran data radioaktivitas tanaman sebelum optimalisasi, seperti terlihat pada Gambar 2(c), dimana data tidak terdistribusi normal. Nilai rata -rata dan standar deviasi data radioaktivitas tanaman baik sebelum maupun setelah optimalisasi diperoleh nilai yang hampir sama, untuk nilai rata-rata sebesar 5,26 Bq/g.abu dan 5,25 Bq/g. abu sedangkan untuk standar deviasi sebesar 1,20 Bq/g.abu dan 1,23 Bq/g.abu. Nilai tertinggi baik sebelum 
Jurnal Iptek Nuklir Ganendra

Ganendra Journal of Nuclear Science and Technology

Vol. 21 No.2, Juli-2021: 93-106

optimalisasi maupun setelah optimalisasi adalah sama yaitu sebesar 9,75 Bq/g.abu. Sebelum optimalisasi nilai terendah sebesar 0,20 Bq/g.abu sedangkan setelah 0,74 Bq/g.abu. Nilai ini berbeda cukup jauh, namun perbedaan pada nilai terendah dapat diabaikan mengingat nilai terendah tidak mempengaruhi hasil evaluasi kegiatan pemantauan radioaktivitas lingkungan. Nilai terendah tidak digunakan dalam kegiatan evaluasi. Nilai data radioaktivitas lingkungan tertinggi yang yang digunakan sebagai evaluasi dibandingkan dengan nilai rona awal lingkungan atau Nilai Ambang Batas (NAB) radioaktivitas lingkungan, apakah masih di bawah NAB atau tidak.

Selain rencana pengurangan lokasi sampling diujicobakan pada data radioaktivitas air, tanah dan tanaman, pengurangan lokasi sampling juga diujicobakan pada data laju dosis radiasi lingkungan sekitar KNY. Hasil uji coba ditampilkan pada Tabel 6 .

Tabel 6. Hasil pengujian percobaan optimalisasi titik sampling menggunakan uji beda t berdasarkan data laju dosis radiasi lingkungan.

\begin{tabular}{|c|c|c|c|c|c|}
\hline \multirow{3}{*}{$\begin{array}{l}\text { Percobaan } \\
\text { ke- }\end{array}$} & \multirow{3}{*}{$\begin{array}{c}\text { Lokasi yang } \\
\text { dipertahankan }\end{array}$} & \multicolumn{4}{|c|}{ Hasil Uji } \\
\hline & & \multirow{2}{*}{$\begin{array}{c}\text { Uji } \\
\text { Normalitas }\end{array}$} & \multirow{2}{*}{$\begin{array}{c}\text { Uji } \\
\text { Homogenitas }\end{array}$} & \multicolumn{2}{|c|}{ Uji Signifikan } \\
\hline & & & & $\begin{array}{c}\text { Independent } \\
\text { test }\end{array}$ & $\begin{array}{c}\text { Man-Whitney } \\
\text { Test }\end{array}$ \\
\hline 6. & $\begin{array}{l}100-2, \\
500-3, \\
1000-3,1000-4 \\
1500-2,1500-3,1500-4 \\
\text { (7 lokasi sampling) }\end{array}$ & $\begin{array}{l}\text { Sig }=0,000 \\
\text { (data tidak } \\
\text { normal) }\end{array}$ & $\begin{array}{l}\text { Sig }=0,130 \text { (data } \\
\text { homogen) }\end{array}$ & $\begin{array}{l}\text { Sig }=0,344 \\
\text { (data tidak beda } \\
\text { signifikan) }\end{array}$ & $\begin{array}{l}\text { Sig }=0,815 \\
\text { (data tidak beda } \\
\text { signifikan) }\end{array}$ \\
\hline
\end{tabular}

Sesuai uji beda t pada data laju dosis lingkungan sekitar KNY memberikan hasil tidak berbeda signifikan antara rerata radioaktivitas seluruh lokasi sampling dan beberapa lokasi sampling sampai radius $1500 \mathrm{~m}$. Oleh karena itu skenario pengurangan lokasi sampling sampai radius $1500 \mathrm{~m}$ dapat dilakukan. Berdasarkan hasil uji coba pada Tabel 3, 4 dan 6 serta sebaran data radioaktivitas setelah optimasi pada Gambar 9 dapat disimpulkan bahwa rencana pengurangan titik sampling air menjadi 9 lokasi dan lokasi sampling tanah dan tanaman menjadi 7 lokasi dapat dilakukan. 7 lokasi sampling yaitu pada lokasi 100-2, 500-3, 1000-3, 1000-4, 1500-2, 1500-3, 1500-4 dan ditambah 2 lokasi sampling air pada lokasi 100-1 dan 100-3. Perubahan lokasi sampling inilah yang akan dijadikan dasar dalam melakukan revisi dokumen RKL RPL PSTA.

\section{KESIMPULAN}

Berdasarkan hasil kajian yang telah dilakukan dapat disimpulkan bahwa dari uji beda $\mathrm{t}$ antara data radioaktivitas air radius 100 - $1000 \mathrm{~m}$ dan data radioaktivitas air seluruh lokasi, radius 100 - $5000 \mathrm{~m}$ diperoleh hasil $S i g=0,001$; hal ini berarti rerata data berbeda signifikan. Uji beda t antara data radioaktivitas air radius $100-1500$ $\mathrm{m}$ dan data radioaktivitas air seluruh lokasi diperoleh hasil $\mathrm{Sig}=0,423$; artinya rerata data tidak berbeda signifikan. Uji beda t untuk data radioaktivitas tanah radius $100-1500 \mathrm{~m}$ diperoleh hasil Sig=0,764. Sedangkan untuk tanaman diperoleh hasil Sig $=0,738$; rerata data tidak berbeda signifikan. Uji beda t antara data laju dosis radiasi lingkungan radius $100-1500 \mathrm{~m}$ dan data laju dosis radiasi lingkungan radius $100-5000 \mathrm{~m}$ diperoleh hasil Sig=0,815; artinya rerata data tidak berbeda signifikan. Data radioaktivitas air, tanah dan tanaman untuk seluruh lokasi sampling memiliki sebaran data yang sama dengan data radioaktivitas air, tanah dan tanaman pada optimalisasi pengurangan titik sampling yaitu sebaran data tidak normal, cenderung condong ke kiri. Berdasarkan hasil kajian ini, direkomendasikan titik sampling radioaktivitas lingkungan dapat dilakukan cukup pada radius $100-1500 \mathrm{~m}$ dari reaktor. Jumlah lokasi pemantauan radioaktivitas air lingkungan sebanyak 9 titik, tanah dan tanaman sebanyak 7 titik.

\section{UCAPAN TERIMA KASIH}

Penulis mengucapkan terima kasih kepada Bapak Mahrus Salam M.Eng dan Bapak Gede Sutresna Wijaya M.Eng yang telah memberikan dukungan dan arahan dalam penyusunan karya tulis ini. Kepada rekan - rekan di Sub Bidang Keselamatan Kerja dan Proteksi Radiasi - BK3, penulis juga mengucapkan terima kasih atas kerjasamanya. 


\section{DAFTAR PUSTAKA}

[1] Chussetijowati J, and $\mathrm{H}$. Seno, "Determination of radioactivity discharge limit to the atmosphere on Bandung nuclear area", Journal of Physics: Conference Series. Vol. 1436. No. 1. IOP Publishing, 2020.

[2] Wijayanto Adi, and Yoo Song Jaec, "The Study of Radiological Environmental Impact Assessments for GA Siwabessy Nuclear Research Reactor in Indonesia", Transactions of the Korean Nuclear Society Autumn Meeting, Yeosu, Korea, 2018.

[3] Dokumen Rencana Pengelolaan Lingkungan (RKL) dan Rencana Pemantauan Lingkungan (RPL), No Dokumen RKPL 001.1/KN 04 04/STA 5.1, PSTA BATAN Yogyakarta, 2016.

[4] Sutondo, Tegas, "Radiation shielding design of neutron source from Kartini reactor's beam-port for SAMOP test facility", Journal of Physics: Conference Series. Vol. 1204. No. 1. IOP Publishing, 2019.

[5] Setiawan, M. Budi, et al., "Evaluation of fuel burn-up and radioactivity inventory in the 2 MW TRIGA-Plate Bandung Research Reactor", Journal of Physics: Conference Series. Vol. 1198. No. 2. IOP Publishing, 2019.

[6] Yuniarto, Arif, and Moh Cecep Cepi Hikmat, "The Study of Atmospheric Dispersion Model on Accident Scenario of Research Reactor GA Siwabessy using HotSpot Codes as A Nuclear Emergency Decision Support System", Jurnal Teknologi Reaktor Nuklir Tri Dasa Mega, Vol. 21, No.1, hal.1-8, 2019.

[7] Zulfakhri, "Radioaktivitas Lingkungan Reaktor TRIGA 2000 PTNBR-BATAN Bandung Tahun 2000-2009", Prosiding Seminar Nasional Sains dan Teknologi Nuklir PTNBR - BATAN Bandung, 2011.

[8] Untara, Ritayanti, Budihari HP., Sri Susilah, A. Yuniarto, Agus Gindo S., Sudiyati, T. Ginting, "Pemantauan Radioaktivitas Lingkungan Di Sekitar Kawasan Nuklir Serpong Tahun 2012", Hasil Penelitian dan Kegiatan PTLR Tahun 2012, ISSN 0852-2979, 2012.

[9] Vasyanovich, M.E., Ekidin, A.A., Vasilyev, A.V., Kryshev, A.I., Sazykina, T.G., Kosykh, I.V., Kapustin, I.A., "Determination of radionuclide composition of the Russian NPPs atmospheric releases and dose assessment to population", Journal of Environmental Radioactivity, Vol. 208,106006, 2019.

[10] Kryshev, I. I., Bulgakov, V. G.,Kryshev, A. I., Katkova, M. N., Sazykina, T. G., Pavlova, N. N., Kosykh, I. V., Gnilomedov, V. D., Buryakova, A. A., Gaziev, I. Ya., "Radioactivity Monitoring of the Surface Air Layer and Atmospheric Fallout Near NPP", Atomic Energy, 2019.

[11] Miftahu Rokhmat, "Laporan Tahunan Kegiatan Pusat Sains dan Teknologi Akselerator (PSTA) BATAN Tahun 2019", Yogyakarta, 2019

[12] Laporan Analisis Keselamatan Reaktor Kartini, Bab 16, Revisi 2 Terbitan 2, No. Dokumen : LAK 001.1/RN.00 03/STA 4, PSTA - BATAN, Yogyakarta, 2019.

[13] Suhartono, Suhartono, and Subiharto Subiharto, "Penentuan Daerah Safety Perimeter Dengan Software Hotspot Versi 3.0. 3 Pada Kecelakaan Reaktor RSG-GAS Pada Daya 5 MW, 10 MW Dan 15 MW", Buletin Reaktor, 2018.

[14] Mohamed, Faizal, Syazwani Mohd Fadzil, And Khoo Kok Siong, "A Study on the Atmospheric Dispersion of Radionuclide Released from TRIGA MARK II Reactor using Gaussian Plume Model", Sains Malaysiana. Vol. 48, No.9, hal. 2021-2028, 2019.

[15] Yuniarto, Arif, Gabriel Soedarmini Boedi Andari, and Syahrir Syahrir, "Pengaruh Tinggi Lepasan Efektif Terhadap Dispersi Atmosferik Zat Radioaktif (Studi Kasus: Calon Tapak PLTN Bangka Belitung)", Jurnal Teknologi Pengelolaan Limbah, Vol. 17, No.1, hal. 63-70, 2014.

[16] Ruan, Qiurong, et al., "Clinical predictors of mortality due to COVID-19 based on an analysis of data of 150 patients from Wuhan, China", Intensive care medicine, Vol. 46, No.5, pp. 846-848, 2020.

[17] Gupta, D. K., et al., "Radionuclides: accumulation and transport in plants", Reviews of Environmental Contamination and Toxicology, Vol. 241, pp.139-160, 2016.

[18] Athoillah, Ibnu, Rini Mariana Sibarani, and Deassy Eirene Doloksaribu, "Analisis Spasial El Niño Kuat Tahun 2015 dan La Nina Lemah Tahun 2016 (Pengaruhnya Terhadap Kelembapan, Angin dan Curah Hujan di Indonesia)", Jurnal Sains \& Teknologi Modifikasi Cuaca, Vol. 18, No.1, hal. 33-41, 2017. 
[19] Yalcin, F., Unal, S., Yalcin, M.G., Akturk, O., Ocak, S.B., Ozmen, S.F., "Investigation of the Effect of Hydrothermal Waters on Radionuclide Activity Concentrations in Natural Marble with Multivariate Statistical Analysis", Symmetry, Vol. 12, No.8, p.1219, 2020.

[20] Yalcin, Fusun, et al., "Estimation of natural radionuclides' concentration of the plutonic rocks in the Sakarya Zone, Turkey using multivariate statistical methods", Symmetry, Vol. 12, No. 6, p.1048, 2020.

[21] Silaban, Bernat, Gim Tarigan, and Partano Siagian, "Aplikasi Mann-Whitney Untuk Menentukan Ada Tidaknya Perbedaan Indeks Prestasi Mahasiswa Yang Berasal Dari Kota Medan Dengan Luar Kota Medan", Saintia Matematika, Vol.2, No. 2, hal.173-187, 2014.

[22] Goss-Sampson, Mark, "Statistical analysis in JASP: A guide for students", 2019.

[23] Marliani, Novi, Hasanuddin Hasanuddin, and Cut Nurmaliah, "Pengaruh Model Pembelajaran Science, Tehcnologi, Society, Environment (STSE) Terhadap Keterampilan Berpikir Kritis Dan Hasil Belajar Siswa Pada Materi Pencemaran Lingkungan Di Mas Jeumala 'Amal", Jurnal EduBio Tropika, Vol. 5, No. 1, hal.3843, 2017. 